\title{
The Rapid Spread of COVID-19 (Corona virus) in Iran, Actions which were taken
}

\author{
Mojtaba Sadeghian* and Mofid Gorji Bandpy \\ Department of Mechanical Engineering, Babol Noshirvani University of Technology, Babol, Iran
}

*Corresponding author: Mojtaba Sadeghian, Department of Mechanical Engineering, Babol Noshirvani University of Technology, Babol, Iran

\begin{tabular}{|c|c|}
\hline ARTICLE INFO & Abstract \\
\hline Received: 幽 April 27, 2020 & \multirow{2}{*}{$\begin{array}{l}\text { Citation: Mojtaba S, Mofid Gorji B. The Rapid Spread of COVID-19 (Corona virus) in Iran, } \\
\text { Actions which were taken. Biomed J Sci \& Tech Res 27(4)-2020. BJSTR. MS.ID.004521. }\end{array}$} \\
\hline Published: May 08, 2020 & \\
\hline
\end{tabular}

\section{Editorial}

Corona viruses are a large family of viruses that cause variety of diseases from cold to more severe illness such as Severe Acute Respiratory Syndrome (SARS-CoV) and Middle East Respiratory Syndrome (MERS-CoV). On February 11, 2020, the novel corona virus disease received an official name by the World Health Organization (WHO), Corona virus Disease 19 (COVID-19) [1] and the International Committee on Taxonomy of Viruses has proposed SARS-CoV-2 as the name of the virus that causes COVID-19 [2]. Common symptoms of this infection include respiratory symptoms, cough, fever, breathing difficulties and shortness of breath. In more severe cases, infections can cause kidney failure, pneumonia, severe acute respiratory syndrome and even death $[3,4]$. The mortality rate for COVID-19 has been much lower than that for SARS in 2003, [5,6] but the transmission has been much greater, creating a higher total death $[5,7]$.The World Health Organization (WHO) has declared the infection a global pandemic. The incidence, severity, and prognosis of this disease are likely to be different in children compared with adults.

The novel corona virus was first detected in Wuhan City, the capital of Hubei Province, with a population of 11 million [8]. On 31 December 2019 the first infected patient experiencing severe respiratory syndrome along with fever, dizziness, and cough. As of February 24, 2020, 79331 confirmed cases and 2618 deaths due to COVID-19 have been reported worldwide [9] and are now a

concerning issue in the world especially in Iran and is spreading rapidly throughout the world. Studies have shown that SARS-CoV was transmitted from wandering cats to humans and MERS-CoV from dromedary camels to humans. Corona viruses are present in human and many different species of animals. Numerous assessments in countries from Asia, Europe, and North America have been published after the first two months of the epidemics of (COVID-19) in the world $[10,11]$. However, there are countries, with a rapid increase and a high number of cases, with a lack of studies $[12,13]$. What has been the focus of attention of health care providers around the world for the last two months has been the problem of the (COVID-19) and its spread to other geographical areas after the outbreak in Wuhan, China [14]. Duo to the spread of the virus, given the mentality of how the Chinese health care system handled the disease and the daily deaths, problems and quarantines associated with it, has been closely monitored by different groups of people in different countries [15]. Unpredictability is one of the most stressful situations along with when to control the disease and the seriousness of the risk. These, along with some analysis and misinformation, can heighten concern among the masses [16]. On the other hand, challenges and stress can cause common mental disorder, such as anxiety and depression [17].

Iran reported its first confirmed cases of (COVID-19) infections on 19 February 2020 in Qom [18], The virus may have been brought to the country by a merchant from Qom who had travelled 
to China [19]. In Iran, on 19 February 2020, two patients in Qom city were confirmed as COVID-19 positive. Afterwards, the illness spread quickly in adjacent provinces near Qom such as Tehran, Isfahan, Semnan, Markazi and shortly in all 31 provinces of the country. Total cases of COVID-19 have rapidly got higher in Iran, with a peak of 44,605 as of March 31. Daily new cases are also picking up speed but still much lower relative to other countries, with 83,505total cases reported on April 20. The total death in the country is 5,650 as of April26. Overall, the recovery rate is reported at 83.5 percent of all cases in Iran as of April .In 26April 2020 Iran has the eighth -highest number of corona virus cases in the world [20]. In response to the corona virus the authorities cancelled public events and Friday prayers; limited travel and they ordered to close universities, schools, bazaars, shopping centers, and holy shrines; and banned festival celebrations. The government initially rejected plans to quarantine entire cities and areas because that required lot of spending, as the result heavy traffic between cities continued ahead of now ruz, following to an increase in the number of new cases, the government later announced a ban on travel between cities. Economic measures were also announced to help families and businesses. Currently Iran is trying to its best to fight with COVID-19, but what is very worrying is the wide widespread of the disease in all the provinces of the country which has made it difficult to control and fight, so that it requires assistance from international organizations such as the WHO. However, what is important is that controlling the disease requires proper and comprehensive management and also it needs attention to mental health care, along with cohesion and relying on social capital, seems to be the only possible way to overcome the current situation.

\section{References}

1. (2019) World Health Organization. Coronavirus disease (COVID-19).

2. Gorbalenya AE, Susan CB, Ralph SB, Raoul J, Christian D, et al. (2020) Severe acute respiratory syndrome-related coronavirus: the species and its viruses, a statement of the Coronavirus Study Group. Bio Rxiv.

3. (2020) Organization WH. Coronavirus: WHO.

4. National Center for Immunization and Respiratory Diseases (NCIRD) DoVD.
5. Ryan O Hare (2020) Crunching the numbers for coronavirus. Imperial News.

6. (2018) High consequence infectious diseases (HCID); Guidance and information about high consequence infectious diseases and their management in England. GOV, UK.

7. (2020) World Federation Of Societies of Anaesthesiologist Corona virus.

8. Rasmussen SA, Smulian JC, Lednicky JA, Wen TS, Jamieson D] (2020) Coronavirus Disease 2019 (COVID-19) and pregnancy: what obstetricians need to know. Am J Obstet Gynecol 222(5): 415-426.

9. Wu F, Zhao S, Yu B, Chen YM, Wang W, et al. (2020) A new corona virus associated with human respiratory disease in China. Nature 579(7798): 265-269.

10. Rodriguez-Morales AJ, Mac Gregor K, Kanagarajah S, Patel D, Schlagenhauf P (2020) Going global - Travel and the 2019 novel corona virus. Travel Med Infect Dis 33:101578.

11. Rodriguez-Morales AJ, Bonilla-Aldana DK, Balbin-Ramon GJ, PanizMondolfi A, Rabaan A, et al. (2020) History isrepeating itself, a probable zoonotic spillover as a cause of an epidemic: the case of 2019 novel Coronavirus. Infez Med 28(1):3-5.

12. Bastola A, Sah R, Rodriguez-Morales AJ, Lal BK, Jha R, et al. (2020) The first 2019 novel coronavirus case in Nepal. Lancet Infect Dis 20(3):279280.

13. Dong E, Du H, Gardner L (2020) An interactive web-based dashboard to track COVID-19 in real time. Lancet Infect Dis 20(5): 534.

14. Bo Xu, Muritz U Creamer (2020) Open access epidemiological data from the COVID-19 outbreak. The Lancet Infectious Diseases, 20(5): 534.

15. Jung SM, Akhmetzhanov AR, Hayashi K, Linton NM, Yang Y, et al. (2020) Real-Time Estimation of the Risk of Death from Novel Coronavirus (COVID-19.Infection: Inference Using Exported Cases. Journal of clinical medicine 9(2): 523

16. Bao Y, Sun Y, Meng S, Shi J, Lu L (2020) 2019-nCoV epidemic: address mental healthcare to empower society. Lancet 395(10224): e37-e38.

17. Dar KA, Iqbal N, Mushtaq A (2017) Intolerance of uncertainty, depression, and anxiety: Examining the indirect and moderating effects of worry. Asian journal of psychiatry 29: 129-133.

18. (2020) Iran Reports Its First 2 Cases of the New Coronavirus. New York Times.

19. Robin Wright (2020) How Iran Became a New Epicenter of the Coronavirus Outbreak. The New Yorker.

20. https://www.worldometers.info/coronavirus/ 
ISSN: 2574-1241

DOI: 10.26717/BJSTR.2020.27.004521

Mojtaba Sadeghian. Biomed J Sci \& Tech Res

(CC) (P) This work is licensed under Creative

Submission Link: https://biomedres.us/submit-manuscript.php

\begin{tabular}{ll} 
BIOMEDICAL & Assets of Publishing with us \\
RESEARCHES & - Global archiving of articles \\
& - Immediate, unrestricted online access \\
\hline issN: $2574-1241$ & - Rigorous Peer Review Process \\
\end{tabular}

